\title{
Lactococcus garvieae infection in the giant freshwater prawn Macrobranchium rosenbergii confirmed by polymerase chain reaction and 16S rDNA sequencing
}

\author{
Shih-Chu Chen ${ }^{1, *}$, Yu-De Lin ${ }^{1}$, Li-Ling Liaw ${ }^{2}$, Pei-Chi Wang ${ }^{1}$ \\ ${ }^{1}$ Department of Veterinary Medicine, National Pingtung University of Sciences and Technology, Pingtung 912, Taiwan, ROC \\ ${ }^{2}$ Culture Collection and Research Center, Food Industry Research and Development Institute, Hsinchu 300, Taiwan, ROC
}

\begin{abstract}
An epizootic bacterial infection in the giant freshwater prawn Macrobranchium rosenbergii occurred in Taiwan from May to June 1999. The cumulative mortality was approximately 30 to $75 \%$. The diseased prawns showed opaque and whitish muscles and were approximately 2 mo old with total lengths from 5 to $6 \mathrm{~cm}$. Histopathologically, they showed marked edema and necrotic lesions with inflammation in the muscles and hepatopancreas. Bacteria isolated using brain heart infusion medium or tryptic soy agar were Gram-positive and ovoid. Three isolates from diseased prawns at different farms were tested using the API 20 Strepsystem and conventional tests and identified as Lactococcus garvieae. Experimental infections with these isolates gave gross signs and histopathological changes similar to those seen in the naturally infected prawns. The $\mathrm{LD}_{50}$ value of isolate MR1 was $6.6 \times 10^{5}$ colony forming units/prawn. Identification of MR1 was confirmed by a PCR assay for $L$. garvieae that gave the expected amplicon of $1100 \mathrm{bp}$. In addition, its 16S rDNA sequence (GenBank accession number AF283499) gave 99\% sequence identity to Enterococcus seriolicida (synonym L. garvieae; GenBank accession number AF061005). This is the first report of confirmed L. garvieae infection in prawn aquaculture.
\end{abstract}

KEY WORDS: Lactococcus garvieae - Giant freshwater prawn · Macrobranchium rosenbergii $\cdot$ PCR · 16S rDNA sequencing

Resale or republication not permitted without written consent of the publisher

\section{INTRODUCTION}

Lactococcus garvieae, a Gram-positive coccus, is an emerging zoonotic pathogen. It has been isolated from cattle, from various species of fish and from humans (Eldar et al. 1996, James et al. 2000). With the development of intensive aquaculture, streptococcal infection of fish has become a major problem worldwide with reports from Japan (Kussuda et al. 1976, Kitao 1993), Taiwan (Tung et al. 1985), Italy (Ghittino \& Prearo 1992, Eldar et al. 1996), Israel (Eldar et al. 1994, 1995),

*E-mail: scchen@mail.npust.edu.tw
Spain (Barrera \& Yortuero 1989, Nieto 1995), France (Nougaryrede 1995), and the United States (Rasheed \& Plumb 1984, Eldar et al. 1995). Although similarity in pathology of fish infected by various Gram-positive cocci does not allow for rapid identification of the causative agents and although isolation and bacteriological analysis are complex and time-consuming, L. garvieae has been identified as one of the major Gram-positive coccus pathogens for fish. Streptococcosis caused by Enterococcus-like bacteria has been observed in rainbow trout Oncorhynchus mykiss (Ceschia et al. 1992, Ghittino \& Prearo 1992, Palacios et al. 1993) and in turbot Scophthalmus maximus (Toranzo et al. 1994). An important disease of cultured yellowtail Seri- 
ola quinqueradiata in Japan was named Enterococcus seriolicida (Kusuda et al. 1991) after previously being classified as Streptococcus (Kusuda et al. 1976). However, taxonomic studies based on DNA-DNA hybridization (Eldar et al. 1996) and sequence analysis of 16S rRNA (Domenech et al. 1993) indicated E. seriolicida (Kusuda et al. 1991) was synonymous with L. garvieae (Eldar et al. 1996). In Spain, a serious septicemic disease of Scopthalmus maximus or large turbot (100 g to $3 \mathrm{~kg}$ ) was accredited to an Enterococcus-like bacterium (Nieto et al. 1995) that was also found to match with L. garvieae (Eldar et al. 1996). Zlotkin et al. (1998) subsequently developed a polymerase chain reaction (PCR) assay based on unique regions of the L. garvieae 16S rRNA gene that allow for its specific identification.

The giant freshwater prawn Macrobranchium rosenbergii is commercially cultured throughout the world and intensively so in Taiwan, where production, however, decreased by 47 to $52 \%$ from 1992 to 1995 (New 1995, Taiwan Fisheries Bureau 1996) due to disease problems. Two diseases have been linked to production decline. One is a yeast infection that occurs mostly in the cool season (October to March), with symptoms including a yellow exoskeleton, a swollen hepatopancreas (HP), milky hemolymph and opaque and whitish muscles (Shu 1993, Cheng \& Chen 1998a). The other is an Enteroccoccus-like infection that occurs mostly in the hot season (June to September, especially during phytoplankton blooms) and causes muscle necrosis (Cheng \& Chen 1988a,b). Recently studies have indicated that mortality in $M$. rosenbergii caused by this bacterium is exacerbated by environmental temperature and $\mathrm{pH}$ parameters that differ from those known to be optimal for prawn growth (Cheng \& Chen 1999c). In this study, the causative bacterium was identified as Lactococcus garvieae by PCR assay and by $16 \mathrm{~S}$ rDNA sequencing.

\section{MATERIALS AND METHODS}

Prawn samples. For histopathological and bacteriological analysis, diseased prawn samples (body weight 2 to $3 \mathrm{~g}$ and 5 to $6 \mathrm{~cm}$ in length) were collected from 3 prawn farms during outbreaks from May to June 1999. Losses were as high as $75 \%$ in some ponds, with average losses of approximately $50 \%$. The prawns had been fed with commercial pellets.

Bacteriology. The cuticle of diseased prawns was surface sterilized by swabbing with $70 \%$ ethanol before being cut open to reveal underlying tissues. Swabs were then taken from muscles and the HP for streaking on tryptic soy agar (TSA), blood agar (BA = TSA $+5 \%$ goat blood), brain heart infusion agar $(\mathrm{BHI})$, and Lowenstein-Jensen medium (LJM). Plates were then incubated at $25^{\circ} \mathrm{C}$. Single colonies were restreaked on the same media to obtain pure isolates. These isolates were then identified using the API Strepsystem and conventional bacteriological tests (Eldar et al. 1996).

Pathology. Muscle tissue, HP tissue and tissues of other internal organs with lesions were fixed in Davidson's fixative and processed for paraffin sectioning. Sections were stained using haematoxylin and eosin (H\&E) and Gram stains and viewed with a light microscope.

Experimental infections. Healthy prawns (Macrobranchium rosenbergii of 2 to $3 \mathrm{~g}$ body weight) were obtained from a prawn farm in Pingtung, Taiwan, and held at a density of 100 prawns in continuously aerated $400 \mathrm{l}$ aquaria containing $300 \mathrm{l}$ of fresh water at approximately $27^{\circ} \mathrm{C}$ for $7 \mathrm{~d}$ until they had been acclimatized to laboratory conditions. They were fed twice daily with commercial prawn pellets and waste was removed daily. Subsequently, 56 prawns of uniform size were selected and subdivided into 8 groups of 7 prawns each. Serial 10-fold dilutions from $2.3 \times 10^{8}$ to $2.3 \times 10^{2} \mathrm{cfu}$ (colony forming units) $\mathrm{ml}^{-1}$ were prepared in sterile normal saline from the purified bacterial isolate Lactococcus garvieae MR1. For each dilution, $0.1 \mathrm{ml}$ was injected intramuscularly (IM) into 7 prawns each of treatment Groups 1 to 7 . Sterile normal saline $(0.1 \mathrm{ml})$ was injected IM into 7 prawns of Control Group 8. After injection, each group was incubated separately in an $80 \mathrm{l}$ aquarium under the same conditions as described above for the acclimatization period. The prawns were continuously monitored for morbidity and mortality and sampled for histopathology and bacteriology.

Bacterial strains. The following bacterial strains were used as controls for PCR assays: Lactococcus garvieae (American Tissue Culture Center, ATCC 43921), Enterococcus seriolicida from rainbow trout (MZ 9101 [KG-] from Dr Terutoyo Yoshida, Miyazaki University, Japan). In addition, the following strains were obtained from the Culture Collection Research Center, Taiwan: Enterococcus faecalis CCRC 10066, Enterococcus durans CCRC 10790, Lactococcus lactis subspecies lactis CCRC10791, Lactococcus lactis subspecies cremoris CCRC 11067, Lactococcus raffinolactis CCRC14039, Enterococcus avium CCRC10801. Three purified bacterial isolates derived from infected prawns were labeled MR1, MR3 and MR4.

Extraction of DNA. For nucleic acid extraction, bacteria were grown at $25^{\circ} \mathrm{C}$ in $\mathrm{BHI}$ broth and harvested by centrifugation at $7000 \times g$ for $45 \mathrm{~min}$ at $4^{\circ} \mathrm{C}$. The pelleted bacteria were then lysed with lysozyme at $30 \mathrm{mg}$ $\mathrm{ml}^{-1}$ for $1 \mathrm{~h}$ at $37^{\circ} \mathrm{C}$, followed by addition of SDS to $5 \%$, $\mathrm{w} / \mathrm{v}$ for $15 \mathrm{~min}$ at $37^{\circ} \mathrm{C}$. Equal volumes of phenol/ chloroform/isoamylalcohol (25:24:1) solution were added 
to the lysate and gently mixed before centrifugation at $12000 \times g$ for $15 \mathrm{~min}$ at $4^{\circ} \mathrm{C}$. The supernatant layer was then collected and DNA precipitated by addition of 0.5 volumes of isopropanol and incubation for $30 \mathrm{~min}$ at $-20^{\circ} \mathrm{C}$ followed by centrifugation at $12000 \times g$ for 15 min at $4^{\circ} \mathrm{C}$. The DNA pellet was washed with $70 \%$ ethanol, dried in a speedvac and then resuspended in $20 \mu \mathrm{l}$ of TE buffer.

Polymerase chain reaction (PCR). The sequences of specific PCR primers for identification of Lactococcus garvieae were obtained from Zlotkin et al. (1998) and comprised pLG-1 (5'-CAT AAC AAT GAG AAT CGC$\left.3^{\prime}\right)$ and pLG-2 (5'-GCA CCC TCG CGG GTT G-3'). These primers targeted a region of the 16S rRNA gene of L. garvieae (EMBL accession no. X54262; Zlotkin et al. 1998) and produced a $1100 \mathrm{bp}$ amplicon. Typical PCRs were carried out in a final volume of $50 \mu \mathrm{l}$ containing $1.25 \mathrm{U}$ of recombinant Taq DNA polymerase (Takara, Japan) per $50 \mu \mathrm{l}, 1 \times$ buffer (Takara, Japan), nucleotides $\left(0.25 \mathrm{mM} \mathrm{l}^{-1}\right.$ final concentration for each nucleotide) and primer (0.5 $\mu \mathrm{M})$. Bacterial DNA (5 $\mu \mathrm{l})$

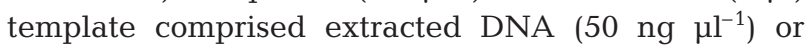
whole cells obtained by touching colonies grown on BHI agar with a toothpick and then dipping the toothpick directly into the PCR mix. Amplification conditions consisted of an initial denaturation step at $94^{\circ} \mathrm{C}$ for $3 \mathrm{~min}$ followed by 35 cycles of denaturation at $94^{\circ} \mathrm{C}$ for $1 \mathrm{~min}$, annealing at $55^{\circ} \mathrm{C}$ for $1 \mathrm{~min}$ and extension at $72^{\circ} \mathrm{C}$ for $1.5 \mathrm{~min}$, except for the last cycle where extension was for $10 \mathrm{~min}$. PCR products $(5 \mu \mathrm{l})$ were subjected to electrophoresis (35 min, $100 \mathrm{~V}$ ) in $2 \%$ agarose gel (SeaKem ${ }^{\circledR}$ LE agarose) with $1 \times$ TBE buffer $(\mathrm{BDH}$ Laboratory supplies) containing $90 \mathrm{mM}$ Tris, $90 \mathrm{mM}$ Borate and 2 mM EDTA ( $\mathrm{pH}$ 8.3) and visualized by UV transillumination with ethidium bromide staining. The DNA molecular weight marker comprised a $100 \mathrm{bp}$ DNA ladder (100 bp [electrophoretic types] ET marker, Chenig Hsin Tang Chemical Co. Ltd, Taiwan).

Sequencing of 16S rDNA. For sequencing, 16S rDNA was amplified by PCR using purified DNA and a primer combination consisting of forward primer $5 \mathrm{~F}$ and reverse primer 1540R (MicroSeq ${ }^{\mathrm{TM}}$ 16S rRNA Gene Kit manufactured by Applied Biosystems). The following conditions were used for amplification: initial denaturation for $10 \mathrm{~min}$ at $95^{\circ} \mathrm{C}$ was followed by 30 cycles of denaturation for $30 \mathrm{~s}$ at $95^{\circ} \mathrm{C}$, annealing for $30 \mathrm{~s}$ at $60^{\circ} \mathrm{C}$ and extension for $45 \mathrm{~s}$ at $72^{\circ} \mathrm{C}$. The amplification was completed by holding the reaction mixture for $10 \mathrm{~min}$ at $72^{\circ} \mathrm{C}$ to allow complete extension of the PCR product. The PCR product was purified with a QIAquick PCR purification kit (Qiagen). Sequencing of the 16S rDNA PCR fragment was carried out using an MicroSeq ${ }^{\mathrm{TM}}$ 16S rRNA Gene Kit manufactured by Applied Biosystems. The manufacturer's recommended protocols were followed. The purified sequencing reac- tion mixtures were automatically electrophoresed using an Applied Biosystems model 310 automatic DNA sequencer. The final sequence of the MR1 PCR fragment was determined from overlapping sequence data using Microseq ${ }^{\mathrm{TM}}$ software (Applied Biosystems). This final sequence was manually aligned with sequences of representative strains retrieved from GenBank, DDBJ and EMBL databases.

\section{RESULTS AND DISCUSSION}

\section{Clinical signs, bacteriology and histopathology}

Most moribund prawns exhibited anorexia, poor growth and a whitish body color. Gross pathological changes included whitish muscle and a swollen, yellowish HP (Fig. 1). Yellowish-white spots were seen on the muscle and varied in size from 0.5 to $2 \mathrm{~cm}$. Smears from fresh HP, muscle tissue and tissues of other internal organs of diseased prawns showed the presence of numerous cocci ranging in size from 0.1 to $0.2 \mu \mathrm{m}$ in diameter. Isolated bacterial colonies from the muscle and HP appeared 1 to $2 \mathrm{~d}$ after streaking on TSA, BA, and BHI.

Histopathologically, diseased prawns showed marked edematous fluid accumulation between the cuticle and underlying muscle tissue (Fig. 2), and there was fragmentation of muscle bundles with liquefaction necrosis. Large numbers of diplococci were detected in muscles of the abdomen, pereiopods and pleopods (Fig. 3). Necrotizing foci encapsulated by hemocytes (granulomas) also appeared in the muscle and HP (Fig. 4). Bacterial microcolonies were seen in the gill hemolymph (Fig. 5). In the HP, desquamated tubulular epithelial cells appeared in tubule lumens and necrotizing foci with bacterial clumps and inflammation were seen in the interstitial spaces (Fig. 6). Necrotic foci and bacterial clumps were also detected in the heart, stomach and other organs.

The diffuse muscle opacity and softening of the exoskeleton described above for white syndrome in Macrobranchium rosenbergii displays some gross pathological changes similar to those for white muscle disease described by Brock (1983). White muscle necrosis or spontaneous necrosis yielding whitish muscle in decapod crustaceans is a condition caused or exacerbated by management and water quality parameters such as handling, crowding, salinity, temperature and low dissolved oxygen (Lakshmi et al. 1978, Brock 1983, Lightner 1983). This opaque and whitish musculature commences at the tail, and progresses to the head, which may then turn red (Lightner 1983). No bacterial cells are associated with this condition and it is reversible during the initial stages of development, if 


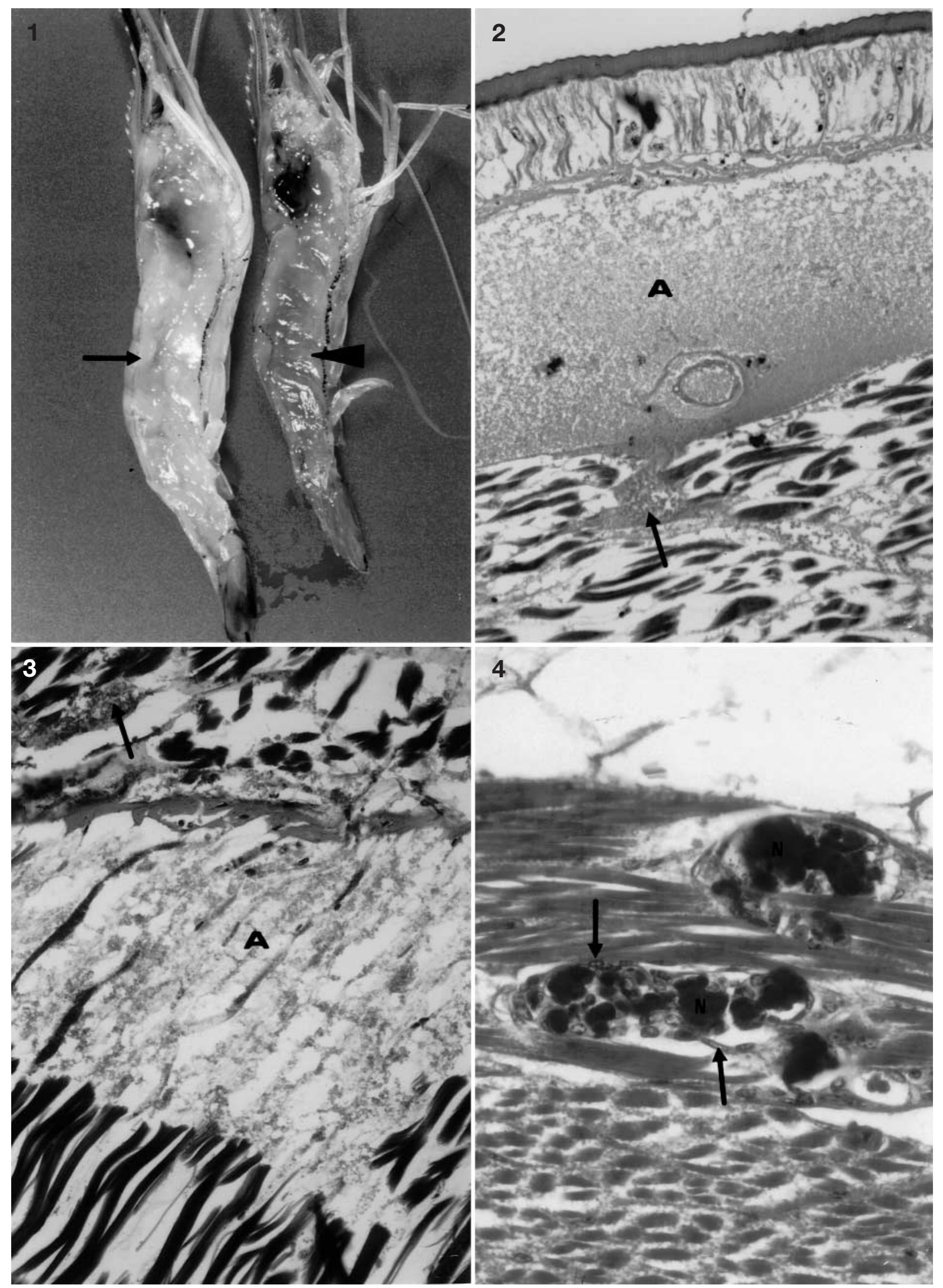


Figs. 1 to 4. Lactococcus garvieae infecting Macrobranchium rosenbergii. Fig. 1. Giant freshwater prawn showing marked opaque and white muscle lesions on the left (arrow) and compared to a normal prawn (arrowhead) on the right. Fig. 2. Giant freshwater prawn tissue section showing edematous fluid (A) accumulated between the cuticle and underlying muscle and muscle bundles (arrow). (H\&E, $\times 200)$. Fig. 3. Giant freshwater prawn tissue section showing marked edematous fluid (A) and necrotizing foci in the muscle together with bacterial clumps (arrow) (H\&E, $\times 400$ ). Fig. 4. Necrotizing foci (N) surrounded by hemocytes (arrows) in muscle tissue. $(\mathrm{H} \& \mathrm{E}, \times \overline{400})$

the causative stress is eliminated. By contrast, the muscle whitening studied herein was previously reported by Cheng \& Chen (1998a) to be a different type of opaque and whitish muscle tissue that developed first in the cephalothorax and then progressed towards the abdomen in association with an Enterococcus-like bacterium that was also found in the HP. Clearly, the 2 conditions are very different.

In earlier publications, we described Enterococcus-like infections from Macrobranchium rosenbergii (Cheng \& Chen 1998a,b) with similar histopathology to those described herein. However, there were also differences. For example, in the current study, marked necrotic areas with edematous fluid, bacterial clumps and granulomas were detected in several organs such as the gills, heart, stomach, and intestine in addition to the muscles and HP, the only organs described as infected in the earlier study by Cheng \& Chen (1998a). The reasons for these differences are unclear but may relate to differences in bacterial strains or rearing conditions.

Biochemical and physiological characteristics of 3 strains of bacteria purified from diseased Macrobranchium rosenbergii (MR1, MR3 and MR4) are shown in Table 1. All 3 were Gram-positive cocci that showed $\alpha$ hemolysis on BA but did not grow in $6.5 \% \mathrm{NaCl}$. All grew over a wide temperature range (4 to $40^{\circ} \mathrm{C}$ ) and in media at $\mathrm{pH} 9.6$ $\left(25^{\circ} \mathrm{C}\right)$. They are compared to reference strains of Enterococcus and Lactococcus in Table 1. All 3 exhibited negative reactions for catalase, oxidase, mannose, sorbital, lactose, trehalose, inulin, raffinose and starch, but a positive reaction for pyruvate. In general, the characteristics of the disease isolates were similar to

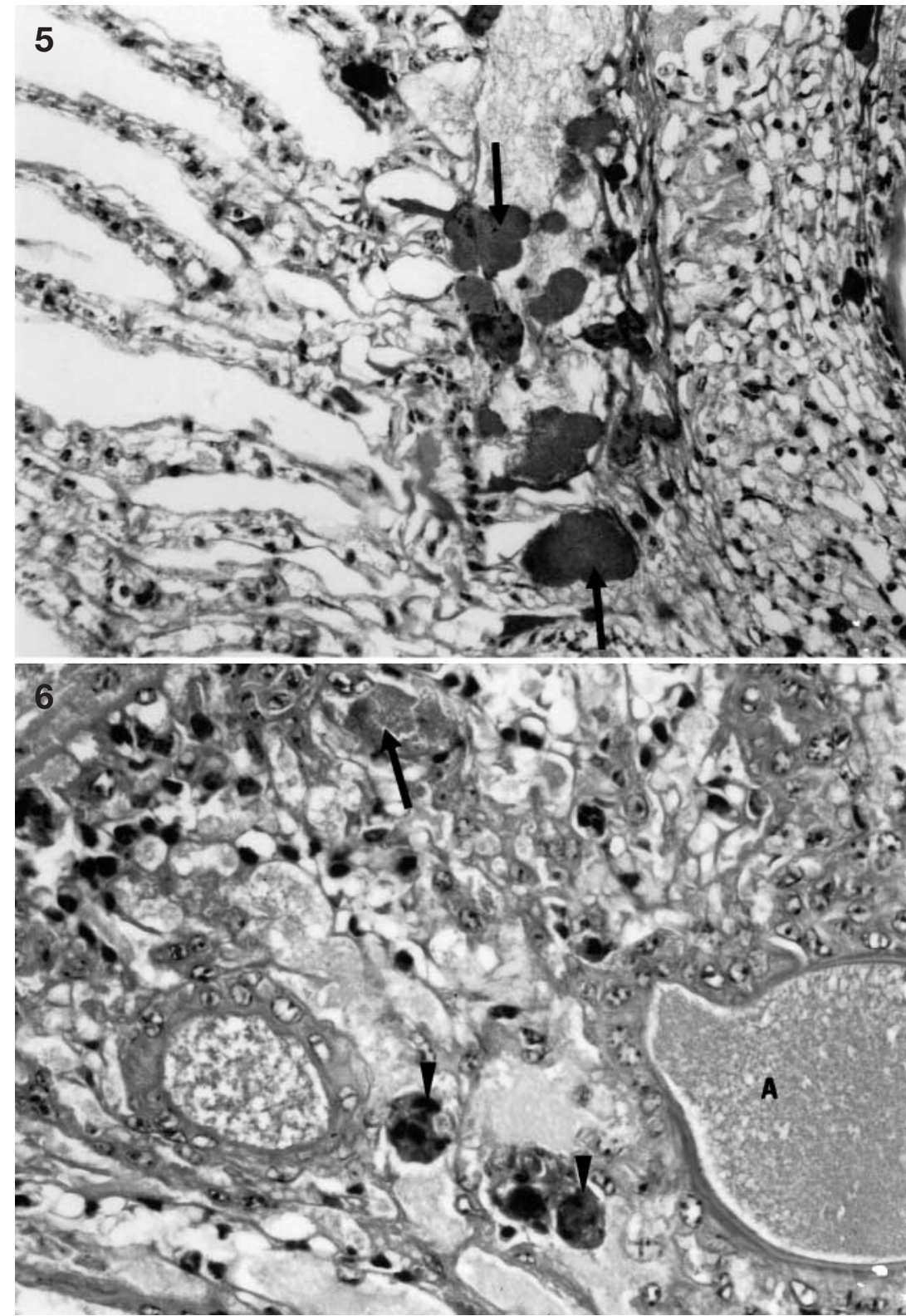

Figs. 5 \& 6. Lactococcus garvieae infecting Macrobranchium rosenbergii. Fig. 5. Infected giant freshwater prawn section showing bacterial microcolonies (arrows) in the gill. $(H \& E, \times 200)$. Fig. 6. Infected giant freshwater prawn tissue section showing bacterial microcolonies (arrow) in the hemal sinus of the hepatopancreas. Also seen are necrotizing foci (arrowheads), edematous fluid (A) and inflammatory cells. $(H \& E, \times 400)$ 
those of L. garvieae and E. seriolicida, but there were some differences. These included major differences for all the isolates in lack of ability to grow at $45^{\circ} \mathrm{C}$ and on media with $\mathrm{NaCl}$ at $6 \%$ or more. There were also minor differences in some assimilation tests for some isolates only. Tests for hemolysis, for hippurate, for salt-tolerance $(6.5 \%)$, for the heat tolerance $\left(45^{\circ} \mathrm{C}\right)$ and for growth at $\mathrm{pH} 9.6$ are important criteria for streptococcus differentiation (Facklam \& Carey 1985, Schleifer \& Kilpper-Balz 1987). According to morphology and the physiological and biochemical tests, the 3 strains isolated from $M$. rosenbergii would be classified in the genus Lactococcus. However, based on the biochemical tests alone, it was difficult to conclude whether or not the isolates were conspecific with L. garviae.

\section{PCR}

PCR assays with DNA extracts of MR1, MR3, MR4, Lactococcus garvieae ATCC43921 and Enterococcus seriolicida (MZ9102) resulted in the amplification of a fragment of $1100 \mathrm{bp}$ (Fig. 7). MR4 data is not shown. PCR assays with DNA extracts from other bacteria including E. faecalis CCRC 10066, E. durans CCRC 10790, L. lactis subspecies lactis CCRC10791, L. lactis subspecies cremoris CCRC 11067, L. raffinolactis CCRC14039 and E. avium CCRC10801 gave no amplicons. When the PCR assay was carried out with 10-fold dilutions of L. garvieae MR1, it gave positive results for the $1100 \mathrm{bp}$ amplicon down to the dilution corresponding to 20 bacterial cells (20 cfu).

Table 1. Biochemical characteristics of bacterial isolates from diseased Macrobranchium rosenbergii compared to the characteristics of reference strains. MR1, MR3 and MR4: strains isolated from M. rosenbergii; ES: Enterococcus seriolicida from rainbow trout (MZ 9101, KG-, from Dr T. Yoshida, Japan); LG: Lactococcus garvieae ATCC 43921; LLSC: L. lactis subspecies cremoris CCRC 11067; LLSL: L. lactis subspecies lactis CCRC10791; LR: L. raffinolactis CCRC14039; EA: E. avium CCRC10801; ED: E. durans CCRC 10790; EF: E. faecalis CCRC 10066. RBC: red blood cells; ATCC: American Tissue Culture Center: CCRC: Culture Collection Research Center, Taiwan

\begin{tabular}{|c|c|c|c|c|c|c|c|c|c|c|c|}
\hline API strepsystem & MR1 & MR3 & MR4 & ES & LG & LLSC & LLSL & LR & EA & ED & $\mathrm{EF}$ \\
\hline Pyruvate & + & + & + & + & + & + & + & + & + & + & + \\
\hline Hippurate & - & - & - & - & - & - & - & - & - & - & - \\
\hline Esculin & - & + & - & + & + & + & + & + & + & + & + \\
\hline Pyrrolldonyl 2-naphthylamide & + & + & - & + & + & - & + & - & + & + & + \\
\hline$\beta$-bromo-2-naphthyl- $\alpha$-D galactopyranoside & - & - & - & - & - & - & - & + & - & + & - \\
\hline Naphthol-AS-BI $\beta$-D glucuronate & - & - & - & - & - & - & - & - & - & - & - \\
\hline 2.naphthyl- $\beta$-D D galactopyranoside & - & - & - & - & - & + & - & - & - & + & + \\
\hline 2.naphthyl phosphate & - & - & - & - & - & - & - & - & - & - & - \\
\hline L-leucine-2-naphthylamide & + & - & - & + & + & + & + & + & - & - & + \\
\hline Arginine & - & + & - & + & + & + & + & - & - & + & + \\
\hline Ribose & - & - & - & + & + & + & + & - & + & + & + \\
\hline L-arabinose & - & - & - & - & - & - & - & - & + & - & - \\
\hline Mannose & - & - & - & + & + & - & - & - & + & - & + \\
\hline Sorbitol & - & - & - & - & - & - & - & - & + & - & + \\
\hline Lactose & - & - & - & - & - & - & - & + & + & + & + \\
\hline Trehalose & - & - & - & + & + & + & + & + & + & - & + \\
\hline Inulin & - & - & - & - & - & - & - & - & + & - & - \\
\hline Raffinose & - & - & - & - & - & - & - & + & + & - & - \\
\hline Starch & - & - & - & + & - & - & + & + & + & + & + \\
\hline Glycogen & - & - & - & - & - & - & - & - & - & - & - \\
\hline Hemolysis (goat RBC) & $\alpha$ & $\alpha$ & $\alpha$ & $\alpha$ & $\alpha$ & $\gamma$ & $\gamma$ & $\gamma$ & $\alpha$ & $\alpha$ & $\gamma$ \\
\hline pH 9.6 & + & + & + & + & + & + & + & - & + & + & + \\
\hline Tolerance at $6.0 \% \mathrm{NaCl}$ & - & - & - & + & + & + & + & - & + & + & + \\
\hline $6.5 \% \mathrm{NaCl}$ & - & - & - & + & + & + & - & - & + & - & + \\
\hline $8.0 \% \mathrm{NaCl}$ & - & - & - & + & - & - & - & - & - & - & + \\
\hline $10 \% \mathrm{NaCl}$ & - & - & - & - & - & - & - & - & - & - & - \\
\hline Growth at $4^{\circ} \mathrm{C}$ & + & + & + & + & + & + & + & + & + & + & + \\
\hline $10^{\circ} \mathrm{C}$ & + & + & + & + & + & + & + & + & + & + & + \\
\hline $15^{\circ} \mathrm{C}$ & + & + & + & + & + & + & + & + & + & + & + \\
\hline $25^{\circ} \mathrm{C}$ & + & + & + & + & + & + & + & + & + & + & + \\
\hline $37^{\circ} \mathrm{C}$ & + & + & + & + & + & + & + & + & + & + & + \\
\hline $40^{\circ} \mathrm{C}$ & + & + & + & + & + & + & + & + & + & + & + \\
\hline $45^{\circ} \mathrm{C}$ & - & - & - & + & + & - & - & - & + & + & + \\
\hline
\end{tabular}


Fig. 7. Specificity of the Lactococcus garvieae PCR assay. Agarose gel (2\%) of PCR products from bacterial DNA templates stained with ethidium bromide. Lane 1: DNA molecular weight marker; Lane 2: L. garvieae ATCC 43921; Lane 3: Enterococcus seriolicida from rainbow trout; Lane 4: E. faecalis CCRC 10066; Lane 5: E. durans CCRC 10790; Lane 6: L. lactis subspecies lactis CCRC10791; Lane 7: L. lactis subspecies cremoris CCRC 11067; Lane 8: E. avium CCRC10801; Lane 9: L. raffinolactis CCRC14039; Lane 10: isolate MR1; Lane 11: isolate MR3

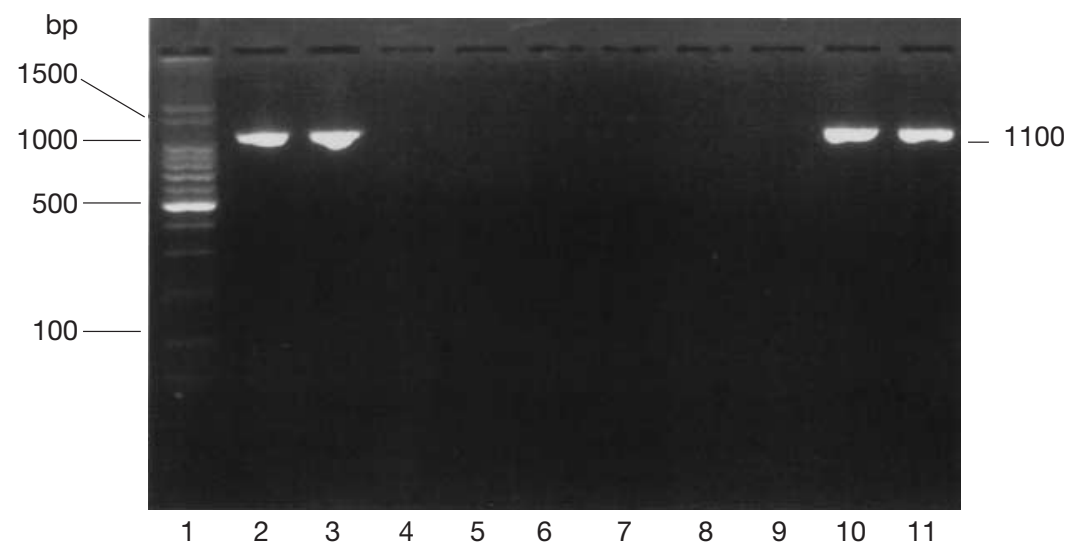

Zlotkin et al. (1998) reported the PCR assay for an amplicon of $1100 \mathrm{bp}$ from 35 strains of Lactococcus garvieae, including L. garvieae ATCC 43921 and Enterococcus seriolicida ATCC 49156 reference strains. If that PCR assay is considered definitive for L. garvieae, then the bacterial isolates obtained from diseased Macrobranchium rosenbergii would have to be considered strains of L. garvieae. In further support of this argument, we found that isolates MR1 to MR4 were resistant to clidamycin, a feature used to distinguish L. garvieae from susceptible L. lactis by Elliott \& Facklam (1996). According to those authors, L. lactis and L. garvieae are phenotypically so similar that the only methods for distinction other than clindamycin susceptibility include comparisons of whole-cell protein patterns, restriction fragment length polymorphism data and nucleic acid sequences (Elliot \& Facklam 1996). To be more confident that the MR isolates corresponded to L. garvieae, the PCR product from MR1 was sequenced and compared to sequences for L. garvieae in public databases.

\section{Sequence of the 16S rDNA PCR amplicon}

The sequence of the $1540 \mathrm{bp}$ PCR amplicon of $16 \mathrm{~S}$ rDNA from isolate MR1 was determined and deposited in the GenBank database under accession number AF283499. This sequence showed 99\% identity with Enterococcus seriolicida (GenBank accession number AF061005), 98\% identity to E. seriolicida (GenBank accession number L32813), $98 \%$ identity to Lactococcus garvieae (DBJ accession number AB012306), 96\% identity to L. garvieae (DDBJ accession number AB018211) and $95 \%$ identity to L. garviae (EMBL, accession number X54262). The sequence comparison results give strong support to the argument that MR1, $L$. garvieae ATCC43921 and E. seriolicida should be assigned to the single species L. garvieae. Eldar et al.
(1996) also argue that $E$. seriolicida is a synonym of $L$ garvieae. The reasons for differences (10 gaps, and 1 base difference) between the sequences for $L$. garvieae MR1 and E. seriolicida (GenBank accession number AF061005), are unclear but may relate to differences in methodology used, in hosts or in bacterial strains.

\section{Experimental infections}

All prawns injected with $2.3 \times 10^{6}$ to $10^{7}$ of bacterial strain MR1 died within $2 \mathrm{~d}$. White muscle and histopathological changes similar to those in naturally infected prawns were seen. The calculated $\mathrm{LD}_{50}$ dose was $6.6 \times 10^{5} \mathrm{cfu} \mathrm{ml}^{-1}$. Pure cultures of bacteria were re-isolated from the HP and muscle of moribund prawns after bacterial challenge and no lesions formed in the control group. Altogether, the results constitute the first confirmation that Lactococcus garvieae can cause disease outbreaks in the giant freshwater prawn Macrobranchium rosenbergii.

Acknowledgements. The authors thank Dr Terutoyo Yoshida Miyazaki University, Miyazaki, Japan, for supplying the bacterial isolate Enterococcus seriolicida MZ9101. This study was supported by the National Science Council, Taiwan, ROC (grants NSC89-2313-B020-029).

\section{LITERATURE CITED}

Barrera J, Tortuero E (1989) Nonhemolytic Streptococcus spp. outbreak in rainbow trout in Spain in diseases of fish and shellfish. Eur Assoc Fish Pathol IV Int Conf, Santiago de Compostela, p 83

Brock JA (1983) Diseases (infectious and noninfectious) metazoan parasites, predator, and public health considerations in Macrobrachium culture and fisheries. In: McVey JP (ed) CRC handbook of mariculture, Vol 1, Crustacean aquaculture. CRC Press, Boca Raton, FL, p 329-370 
Ceschia G, Giorgetti G, Giavenni R, Sarti M (1992) A new problem for Italian trout farms: streptococcosis in rainbow trout (Oncorhynchus mykiss). Bull Eur Assoc Fish Pathol 12:71-72

Cheng W, Chen JC (1998a) Isolation and characterization of an Enterococcus-like bacterium causing muscle necrosis and mortality in Macrobrachium rosenbergii in Taiwan. Dis Aquat Org 34:93-101

Cheng W, Chen JC (1998b) Enterococcus-like infections in Macrobrachium rosenbergii are exacerbated by high $\mathrm{pH}$ and temperature but reduced by low salinity. Dis Aquat Org 34:103-108

Cheng W, Chen JC (1998c) Effect of cultivation broth pH, temperature and $\mathrm{NaCl}$ concentration on virulence of Enterococcus-like bacterium to the giant fresh prawn Macrobrachium rosenbergii. Dis Aquat Org 36:233-237

Domenech A, Prieta J, Fernandez-Garayzabal JF, Collins MD, Jon D, Dominguez L (1993) Phenotypic and phylogenetic evidence for a close relationship between Lactococcus garvieae and Enterococcus seriolicida. Microbiologica 9: 63-68

Eldar AC, Bejerano Y, Bercovier H (1994) Streptococcus shiloi and Streptococcus difficile: two new streptococcal species causing a meningoencephalitis in fish. Curr Microbiol 28: 139-143

Eldar AC, Frelier PF, Asanta L, Varner PW, Lawhon S, Bercovier H (1995) Streptococcuss shiloi, the name for an agent causing septicemic infection in fish, is a junior synonym of Streptococcus iniae. Int J Syst Bacteriol 45: 840-842

Eldar AC, Ghittino C, Asanta L, Bvozzettz E, Goria M (1996) Enterococcus seriolicida is a junior synonym of Lactococcus garvieae, a causative agent of septicemia and meningoencephalitis in fish. Curr Microbiol 32:85-88

Elliott JA, Facklam RR (1996) Antimicrobial susceptilities of Lactococcus lactis and Lactococcus garvieae and a proposed method to discriminate between them. J Clin Microbiol 34:1296-1298

Facklam RR, Carey RB (1985) Manual of clinical microbiology, 4th edn. In: Lennette EH, Ballows A, Hausler WJ Jr, Shadomy HJ (eds) Streptococci and Aerococci. American Society for Microbiology, Washington, DC, p 154-175

Ghittino C, Prearo M (1992) Segnalazione di Streptococcosi nella trota iridea (Oncorhynchus mykiss) in Italia: nota preliminare. Boll Soc Ital Pathol 8:4-11

James PR, Hardman SM, Patterson DL (2000) Osteomyelitis and possible endocarditis secondary to Lactococcus garvieae: a first case report. Postgrad Med J 76:301-303

Kitao T (1993) Streptococcal infection. In: Inglis V, Roberts RJ, Bromage NR (eds) Bacterial diseases of fish. Blackwell

Editorial responsibility: Timothy Flegel, Bangkok, Thailand, and Carey Cunningham, Aberdeen, Scotland, UK
Scientific Publications, Oxford, p 196-210

Kusuda R, Kawai K, Toyoshima T, Komatsu I (1976) A new pathogenic bacterium belonging to genus Streptococcus isolated from an epizootic of cultured yellowtail. Bull Jpn Soc Sci Fish 42:1345-1352

Kusuda R, Kawai K, Salati F, Banner CR, Fryer JL (1991) Enterococcus seriolicida sp. nov., a fish pathogen. Int J Syst Bacteriol 41:406-409

Lakshmi GJ, Venkataramiam A, Howse HD (1978) Effect of salinity and temperature changes on spontaneous muscle necrosis in Penaeus aztecus. Aquaculture 13:35-43

Lightner DV (1983) Diseases of culture penaeid shrimp. In: McVey JP (ed) CRC handbook of mariculture, Vol 1, Crustacean aquaculture. CRC Press, Boca Raton, FL, p 289-320

Murray BB (1990) The life and times of the Enterococcus. Clin Microbiol Rev 3:46-65

New MB (1995) Status of freshwater prawn farming: a review. Aquacult Res 3:46-65

Nieto JM, Devasa S, Quiroga A, Toranzo AE (1995) Pathology of Enterococcus sp. infection in farmed turbot, Scophthalmus maximus L. J Fish Dis 18:21-30

Nougayrede P, Michel C, Sochon E, Vuillaume A, de Kinkelin P (1995) Vagococcosis: an emerging threat to farmed salmonid populations in diseases of fish and shellfish. Eur Assoc Fish Pathol VII Int Conf, Palma de Mallorca, p 26

Palacios MA, Zamora MJ, Velazqez J, Zamora E, Duran A (1993) Streptococcus in rainbow trout (Oncorhynchus mykiss) in Spain. Boll Sci Ital Pathol 13:11-14

Rasheed V, Plumb JA (1984) Pathogenicity of a nonhaemolytic group B Streptococcus sp. in Gulf kill-fish Fundulus grandis. Aquaculture 37:97-105

Schleifer KH, Kilpper-Baz R (1987) Molecular and chemotaxnomic approaches to the classification of streptococci, enterococci and lactococci: a review system. Appl Microbiol 10:1-9

Shu JP (1993) Studies on yeast infection in cultured giant freshwater prawn, (Macrobranchium rosenbergii). MS thesis, Dept Veterinary, Chung-Hsing University, Taiwan

Taiwan Fisheries Bureau (1996) Fisheries yearbook Taiwan area 1994. Taipei

Toranzo AE, Devesa S, Heinen P, Riaza A, Nunez S, Barja JL (1994) Streptococcosis in cultured turbot caused by an Enterococcus-like bacterium. Bull Eur Assoc Fish Pathol 14:19-23

Tung MC, Chen SC, Tsai SS (1985) General septicemia of Streptococcus infection in caged cultured tilapia in Southern Taiwan. COA Fisheries Series No. 4. Reports on Fish Diseases Research (VII). Taipei, p 95-105

Zlotkin A, Eldar A, Ghittino C (1998) Identification of Lactococcus garvieae by PCR. J Clin Microbiol 36:983-985

Submitted: September 4, 2000; Accepted: January 14, 2001 Proofs received from author(s): April 18, 2001 